\title{
Prawo karne Królestwa Polskiego w latach 1815-1905 a sprawowanie kultu religijnego
}

Wolność kultu religijnego w Królestwie Polskim w latach 1815-1905 jest zagadnieniem zawiłym. Aby lepiej zrozumieć wpływające na nią działania rządzących, konieczne jest zapoznanie się m.in. z tłem historycznym, rolą prawosławia będącego religią panującą w Imperium Rosyjskim oraz polityką i stosunkiem poszczególnych carów do wyznań. Wszystko to jest materiałem na obszerną monografię, dlatego niniejszy artykuł ma na celu zapoznać przede wszystkim z ówczesnym prawem karnym, dotyczącym stricte sprawowania nabożeństw, oraz zwrócić uwagę na przepisy regulujące działalność misyjną, która jest związana ściśle z publiczną aktywnością duszpasterską. To opracowanie tylko wspomina o niektórych zmianach, które przyniosła ze sobą liberalizacja przepisów wyznaniowych z 1906 r., ponieważ zadowalające ich przedstawienie w formie artykułu wydaje się niemożliwe. Dlatego ten artykuł poświęcony jest przede wszystkim prawu obowiązującemu do 1905 r., a późniejsze doniosłe zmiany jedynie sygnalizuje.

W latach 1815-1905 wolność religijną określał szereg aktów normatywnych różnego rzędu, w tym nieopublikowanych, stanowionych zarówno przez władze centralne, jak i organy terenowe. W całym Imperium Rosyjskim wydanych praw było tak wiele, że ministrowie opracowujący ukazy tolerancyjne z lat 1905-1906 zwrócili uwagę, że w gąszczu dotyczących kultu przepisów

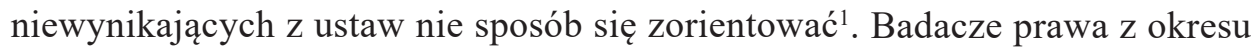

\footnotetext{
1 Jak podniósł komitet ministrów, „oto w dziedzinie tej rozwinęło się na szeroką skalę stosowanie rozporządzeń administracyjnych ze strony różnych władz, które, nie znajdując w ustawie norm odpowiadających nowym wymaganiom życia, i unikając poruszania nowych zagadnień na skomplikowanej drodze prawodawczej, nieraz same tworzyły sobie przepisy, jakie się im zdawały
} 
Polski międzywojennej nie byli zgodni co do tego, jakie prawo obowiązywało i jak było wykonywane.

27 listopada 1815 r. została podpisana przez cara Aleksandra I Konstytucja Królestwa Polskiego ${ }^{2}$. Choć dopuszczała ona dyskryminację wyznaniową niechrześcijan, deklarowała wolność kultu. Jej art. 11 stanowił, że „religia katolicko-rzymska wyznawana przez największą część mieszkańców Królestwa Polskiego będzie przedmiotem szczególniejszej opieki rządu, nie uwłaczając przez to wolności innych wyznań, które wszystkie bez wyłączenia obrządki swe całkowicie i publicznie pod protekcją rządu odbywać mogą. Różność wyznań chrześcijańskich nie będzie stanowić żadnej przeszkody w używaniu praw cywilnych i politycznych".

Administracja nie traktowała zacytowanej normy jako przepisu bezwzględnie obowiązującego, uważając ją za ogólną deklarację. W zależności od subiektywnego stosunku do danego wyznania terenowe władze wojewódzkie oraz obwodowe potrafiły udaremnić organizowanie nabożeństw powołując się na przepisy policyjne lub wydając rozporządzenia o zakazie zbierania się danej grupy, nawet w domach prywatnych ${ }^{3}$. W świetle praktyki administracyjnej i stanowionych praw ustawa zasadnicza nie wywarła (do czasu jej zastąpienia po upadku Powstania Listopadowego Statutem Organicznym Królestwa Polskiego z dnia 14/26 lutego 1832 r. $)^{4}$ większego wpływu na swobody wyznaniowe. Podobnie sam Statut, który ograniczając autonomię Królestwa Polskiego utrzymał dotychczasowe przepisy wyznaniowe, z wyjątkiem kwestii związanych ze zmianą ustroju sprawowania władzy (brak Senatu, w którym zasiadali biskupi).

Ogłoszony w dniu 28 lipca 1818 r. Kodeks Karzący Królestwa Polskiego ${ }^{5}$ zastąpił uprzednio obowiązujące regulacje Księstwa Warszawskiego oparte, w zależności od regionu, na prawach pruskich, austriackich oraz polskich przedrozbiorowych, stosowanych tak, aby nie naruszać postanowień konstytucji, jak i Kodeksu Napoleona, hołdującego zasadom świeckiego państwa.

Nowe prawo karne oraz następujące po nim kodyfikacje penalne były filarem nietolerancyjnej polityki wyznaniowej. Zwalczały one ateizm, sekciarstwo i roz-

niezbędnemi. Z drugiej strony, na niektórych kresach Cesarstwa, zamieszkałych przez zwarte masy innowierców, spokojny rozwój państwowości rosyjskiej niekiedy zakłócały zaburzenia natury politycznej, wywołujące szereg rozporządzeń ograniczających, między innemi, i w bycie religijnym ludności inowierczej” - Franciszek Nowodworski, Tolerancyja religijna, „Gazeta Sądowa Warszawska”, 1905, nr 22, s. 347.

${ }^{2}$ Dziennik Praw Królestwa Polskiego t. 1, nr 1, s. 1-102.

${ }^{3}$ Przykłady takiego działania podaje M.Wodziński, ,,Sprawa chasydymów”. Z materiałów do dziejów chasydyzmu w Królestwie Polskim, [w:] Z historii ludności żydowskiej w Polsce i na Ślasku, Wrocław 1994, s. 227-242.

${ }^{4}$ Dziennik Praw Królestwa Polskiego t. 14, nr 55, s. 172-249.

${ }^{5}$ Dziennik Praw Królestwa Polskiego t. 5, nr 20, s. 3-292. 
wój wspólnot niechrześcijańskich. Z biegiem czasu stopniowo ograniczały, wraz z przepisami im towarzyszącymi, propagandę religijną wszystkich wyznań poza prawosławnym - oraz odprawianie nabożeństw publicznych i domowych.

Kodeks Karzący Królestwa Polskiego surowo karał gwałtowne przeszkadzanie obrządkom którejkolwiek uznanej religii oraz szydzenie z przedmiotów kultu mową, czynami i pismem. Jeżeli wymienione przestępstwa dawały powód do zgorszenia lub powszechnego niebezpieczeństwa groziła za nie kara od 3 do 10 lat ciężkiego więzienia (art. 77-79). Ścigane były również osoby, które namawiały chrześcijan do porzucenia wyznania oraz zakładały bądź usiłowały tworzyć sekty (art. 257).

Mimo że Kodeks nie pozwalał legalnie działać nowym wspólnotom, to administracja podejmowała inicjatywy szykanujące aktywność od dawna istniejących grup wiernych, chcąc doprowadzić do ich upadku. Przykładem jest sprawa żyjących w Polsce od XVIII wieku chasydów, którzy w 1823 r. uzyskali zezwolenie od namiestnika Królestwa Polskiego Józefa Zajączka na spotykanie się w celach kultu religijnego. Mimo pozwolenia otrzymali oni od władz następujące pouczenie: ,sekcie Chasidim wykonywanie nabożeństw po domach zostało dozwolone, gdy jednak nie upatruje (Komisja RSWiP) żadnego usprawiedliwienia, aby decyzja ta rozciągnąć się miała do wolnego zbierania się Żydów z różnych okolic, ile że w każdym miejscu to wspólnie między sobą dopełnić mogą, a przebywanie $\mathrm{z}$ stron odległych w tym celu nie tylko na bezpotrzebne naraziło ich koszta, ale nadto jako przeciwne przepisom policyjnym i ułatwiające włóczęgostwo cierpiane by być nie mogło".

Obowiązujący od 1 stycznia 1848 r. Kodeks Kar Głównych i Poprawczych ${ }^{7}$ poszerzył zakaz propagandy religijnej w ten sposób, że nie wolno było nawracać na jakiekolwiek wyznanie osób choćby tylko formalnie prawosławnych. Duchowni innych wyznań nie mieli prawa świadczyć im posług religijnych pod groźbą surowych kar. Dopiero na skutek wejścia w życie Ukazu z dnia 14/27 marca 1906 r., dotyczącego wprowadzenia niektórych przepisów wyznaniowych kodeksu Tagancewa ${ }^{8}$, karalne było tylko skłonienie chrześcijanina do przejścia na wiarę niechrześcijańską za pomocą nadużycia władzy, przymusu, oszustwa lub uwiedzenia obietnicą korzyści.

W Królestwie Polskim nie została wprowadzona możliwość swobodnej zmiany wyznania. Przełomowy Ukaz z dnia 17/30 kwietnia 1905 r. o utwierdzeniu zasad tolerancji religijnej, choć wskazywał, że konwersja z wiary prawosławnej na inne chrześcijańskie wyznanie lub obrządek jest legalna, to chrześcijanin mógł

\footnotetext{
${ }^{6}$ M.Wodziński, op.cit., s. 242.

7 Dziennik Praw Królestwa Polskiego t. 40, nr 123, s. 3-111.

8 J. Kirszrot, Prawa Żydów w Królestwie Polskim, Warszawa 1917, s. 24.
} 
przyjąć wyznanie niechrześcijańskie tylko takie, które uprzednio wyznawał bądź wyznawali jego przodkowie (zasadność zmiany wyznania podlegała weryfikacji). Prawo utrzymywało paradoks, w którym to praktykujący niechrześcijanie byli formalnie chrześcijanami, co wiązało się z istotnymi niedogodnościami, zwłaszcza na gruncie prawa małżeńskiego i powiązanego z nim religijnego wychowywania dzieci. Formalna różnica wyznania w niektórych przypadkach była przeszkodą w zawarciu małżeństwa wywierającego skutki cywilne ${ }^{9}$ oraz nie pozwalała legalnie uczestniczyć w obrzędach niektórych wyznań do czasu reformy prawa karnego.

Przepisy karne ograniczające prawo do kształtowania własnego światopoglądu i manifestowania go zostały rozbudowane i zaostrzone na mocy dopuszczającego analogię ${ }^{10}$ Kodeksu Kar Głównych i Poprawczych. Nakładał on na wyznawców wszystkich religii obowiązek zapobiegania odstępstwom od wiary prawosławnej. Kary miały charakter odstraszający. Penalizowane było:

- porzucenie prawosławia oraz przeszkadzanie dobrowolnemu przejściu na prawosławie,

- nieprzeszkadzanie podopiecznym i członkom rodziny w porzuceniu prawosławia.

Kara polegająca na odebraniu dzieci i oddaniu ich krewnym prawosławnym względnie wyznaczonemu przez państwo opiekunowi groziła rodzicom, którzy wbrew ciążącemu na nich obowiązkowi, zamiast wychowywać dzieci zgodnie z zasadami Kościoła prawosławnego poddawali je sakramentowi chrztu lub innym sakramentom i wychowywali zgodnie z zasadami odmiennego chrześcijańskiego wyznania. W skrajnych przypadkach osobie chcącej nawrócić wyznawcę religii panującej groziło pozbawienie wszelkich praw i zesłanie na Syberię albo do robót ciężkich, względnie robót w kopalniach od 12 do 15 lat ${ }^{11}$. Art. 168

${ }^{9} \mathrm{~W}$ b. zaborze rosyjskim, jak i całej Rosji innym ograniczeniem związanym z samostanowieniem religijnym był brak możliwości zadeklarowania ze skutkiem prawnym bezwyznaniowości. Choć trwały prace nad wprowadzeniem takiej możliwości, to komisja opracowująca ukaz tolerancyjny zajęła ostatecznie stanowisko, że religia jest główną ostoją moralności, a osoby areligijne są skore do bezprawia.

${ }^{10}$ Przepis art. 156, dopuszczający analogię, był doskonałym narzędziem represji, albowiem przy zastosowaniu odpowiedniej wykładni istniała możliwość ukarania niemal każdego. Omawiany przepis stanowił, że ,jeżeli, na przestępstwo przychodzące pod rozpoznanie sądu, prawo nie postanowiło oznaczonej kary, wówczas sąd skazuje winnego na jedną z kar postanowionych na przestępstwa, najwięcej do rzeczonego przestępstwa z rodzaju i ważności swej zbliżone; wstrzymuje się jednak z wykonaniem wyroku i przedstawia go w porządku właściwym władz, do rozpoznania Rządzącego Senatu”.

${ }^{11}$ Kodeks w art. 194 wskazywał na brak możliwości odstąpienia od prawosławia stanowiąc, że ,przechodzący z Prawosławnego wyznania na inne chrześcijańskie odesłanym zostanie do zwierzchności duchownej dla upomnienia, nauki i postąpienia z nim, podług prawideł kościoła”. 
stanowił, że przedawnienie nie umarza kar za przejście z prawosławia na inne dozwolone chrześcijańskie wyznanie oraz za odstąpienie zupełne od wiary chrześcijańskiej, albowiem przestępstwa te trwały dopóki winni nie powrócili (w przypadku prawosławnych) bądź nie wstąpili do usankcjonowanego prawem wyznania chrześcijańskiego (pozostali chrześcijanie). Niektóre przestępstwa, nie tylko stricte religijne, ale popełniane przez chrześcijan były karane pokutą kościelną.

Przedstawione regulacje miały doprowadzić z czasem do zlikwidowania sekt, gdyż prócz tego, że zawierały nazwy przykładowych nielegalnych zgromadzeń, zabraniały rozwijać się już istniejącym i tolerowanym ${ }^{12}$. Przepis art. 209 stanowił, że ,za założenie odszczepieńskich zborów lub osad i za wystawienie budowli do nabożeństwa pod nazwą kościołów, kaplic lub domów modlitwy oraz za zamienienie domów włościańskich w publiczne odszczepieńskie domy modlitwy winni ulegną karze osadzenia w wieży od roku jednego do dwóch lat, stosownie do stopnia winy".

Kodeks Kar Głównych i Poprawczych wymieniał również szereg przestępstw dotyczących niewłaściwego zachowania się w miejscach kultu oraz w ich sąsiedztwie i względem duchownych. Część wymienionych w nim czynów mogła zostać popełniona tylko względem legalnie działających religii chrześcijańskich. Niektóre kary zależne były od wyznania sprawcy. Silniejszą ochronę wyznań chrześcijańskich powielały także późniejsze carskie kodeksy. Na ziemiach Kongresówki dopiero od 1 września 1932 r., kiedy to weszło w życie Rozporządzenie Prezydenta Rzeczypospolitej z dnia 11 lipca 1932 r. Kodeks Karny ${ }^{13}$ prawo karne nie uzależniało karalności od wyznania.

Niechęć do nowych związków wyznaniowych została również zamanifestowana w Ustawie z dnia 19/31 grudnia 1866 r. o Zarządzie Gubernialnym i Powiatowym w Guberniach Królestwa Polskiego ${ }^{14}$, w której to w art. 12 wskazano, że „Gubernator ściśle przestrzegając zapewnioną wszystkim poddanym państw rosyjskich wolność wiary strzeże legalnych praw i nietykalności Kościoła Prawosławnego, oraz wszelkich innych wyznań, przez prawo uznanych i pilnuje, ażeby mieszkańcy powierzonej mu guberni w wyznawaniu swojej wiary, nie doznawali

12 Art. 202 „Ktoby istniejące już kacerstwo i odszczepieństwo od Prawosławnego kościoła rozszerzał, lub nową sektę dla wiary szkodliwą zaprowadził, ukaranym zostanie: pozbawieniem wszelkich praw i zesłaniem na osiedlenie za Kaukazem”. Osoby zdatne do służby wojskowej zamiast osiedlenia za Kaukazem były wcielane jako szeregowi do korpusu kaukaskiego (art. 81).

${ }^{13}$ Dz.U. z 1932 r. nr 32 poz. 60. Odzyskanie przez Polskę niepodległości oraz uchwalenie deklarującej w art. 96 równouprawnienie Konstytucji z dnia 17 marca 1921 r. (Dz.U. z 1921 r. nr 44 poz. 267) nie spowodowało milczącego uchylenia szeregu porosyjskich nietolerancyjnych przepisów karnych.

${ }^{14}$ Dziennik Praw Królestwa Polskiego t. 66, nr 219, s. 114-198. 
nieprawnych ograniczeń i ścieśnień. Gubernator osłania każde wyznanie od przeciwnego prawu targnięcia się na nie ze strony innych wyznawców i przestrzega, ażeby duchowieństwo, tak świeckie jako i zakonne ściśle wykonywało przepisy dlań prawami cywilnymi ustanowione".

Przepisy Królestwa Polskiego mogły wydawać się liberalne w porównaniu z chociażby guberniami zachodnimi, które weszły w skład odrodzonego po I Wojnie Światowej państwa polskiego. Tam obowiązywało ogłoszone w 1857 r. Rozporządzenie Komisji Rządowej Spraw Wewnętrznych i Duchownych o przeciwdziałaniu i zapobieganiu przestępstwom ${ }^{15}$. Jego przepisy w art. 18-22 zawierały nakaz chodzenia przez osoby wyznania prawosławnego do corocznej spowiedzi oraz przystępowania do komunii. Co do zasady duchowni musieli czuwać nad wypełnianiem powyższych nakazów przez wiernych przez prowadzenie i dostarczanie zwierzchności duchownej imiennego spisu parafian z wyszczególnieniem tych, którzy spowiedź odbyli. Przepis art. 22 stanowił, że: „ktoby zaś, pomimo napomnien duchownego, przez dwa lub trzy lata nie był u spowiedzi i u komunii, podlega pokucie kościelnej, a gdy i wtedy się nie skruszy i długu chrześcijańskiego nie spełni, natenczas zwierzchność duchowna zawiadomi o tem władzę cywilną do jej uznania".

Wart uwagi jest jeszcze art. 38 Rozporządzenia stanowiący, że „osobom, które od wiary prawosławnej odstąpiły, zabrania się, aż do powrotu ich do prawosławia, mieszkać w dobrach, przez prawosławnych zaludnionych. Dobra zaś te na cały ów czas winny być wzięte w opiekę, do której nie może atoli należeć ani mąż odpadłej od prawosławia kobiety, ani też żona zdrajcy prawosławia" oraz art. 41 o treści: „urodzeni i wychowani w wierze prawosławnej, mieszkający w jednych wsiach z nowoochrzczonymi na prawosławie, baczyć powinni na postępki nowochrzceńców; jeśli zaś z tych ktośkolwiek nie tak postępuje, jak przystoi prawowiernemu, nie bywa w cerkwi i trzyma się obyczajów innowierczych, powinni go zrazu przekonywać, a gdy nie posłucha, zameldować mają o tem duchownym parafijalnym, którzy postąpią z nim wedle przepisów, podanych w ustawach kościelnych".

Ukazem z dnia 13/25 września 1876 r. car wprowadził na terenie Królestwa Polskiego rosyjski kodeks karny z 1866 r. ze wskazanymi przez siebie wyjątkami. Zmiana ta nie miała większego znaczenia dla obowiązującego w Królestwie Polskim prawa wyznaniowego, ponieważ obowiązujące dotychczas regulacje oparte były na tych samych założeniach co kodeks karny rosyjski z 1845 r., którego poniekąd nowym wydaniem był kodeks z $1866 \mathrm{r}$. Istotną zmianą kodeksu z $1866 \mathrm{r}$. było wydzielenie $\mathrm{z}$ niego szeregu drobnych przestępstw, które przekazano do roz-

${ }^{15}$ Historia Państwa i Prawa Polski, red. J. Bardach, t. 4, Warszawa 1981, s. 120. 
poznania sędziom pokoju ${ }^{16}$. Na ziemiach Kongresówki nie został przyjęty carski przepis stanowiący, że tylko osoby prawosławne mogą aktywnie nawracać na swoją wiarę wyznawców innych religii. Wszystkie uznane wyznania chrześcijańskie mogły prowadzić działalność misyjną w stosunku do wyznawców wszystkich innych religii prócz prawosławnej, co miało istotny wpływ na sprawowanie kultu publicznego i prywatnego. Sytuacja ta uległa zmianie na mocy „Najwyżej zatwierdzonego dnia 20 września/2 października 1876 r. postanowienia b. komitetu do spraw Królestwa Polskiego o pozostawieniu niektórym urzędnikom administracyi miejscowej w okręgu sądowym warszawskim władzy wymierzania kar". Mocą tego aktu zabroniono mieszania się duchownych katolickich w sprawy innych wyznań w sposób zawierający obrazę przepisów o tolerancji albo mający na celu sianie propagandy katolickiej ${ }^{17}$.

Prawo do organizowania nabożeństw domowych dla zaproszonych gości nie było równe dla wszystkich wyznań i z czasem zostało poddane ograniczeniom. Jednym z przepisów mających za zadanie je udaremniać był $\S 133$ ust. 5 Ustawy z 8/20 lutego 1849 r. o Kościele Ewangelicko-Augsburskim w Królestwie Polskim ${ }^{18}$, nakładający na konsystorz obowiązek ,czuwania nad tem, iżby pod żadnym względem nie miały miejsca zgromadzenia, w celu odbywania modlitw i nabożeństw prywatnych i pokątnych". Można się domyślać, że przepis ten podyktowany był tym, że władza nie chciała dopuścić do tworzenia się nowych protestanckich związków wyznaniowych. Obawy rządu co do lojalności ewangelików budziły napływające informacje, jakoby luteranie w Królestwie Prus utworzyli fanatyczny kościół wraz z wieloma podobnymi mu sektami. Podmioty te miały, według otrzymywanych raportów, prowadzić działalność na szkodę Królestwa Polskiego oraz tylko warunkowo uznawać władze państwa ${ }^{19}$.

Jakiejkolwiek swobodzie prywatnego kultu tamę położyło rozporządzenie Namiestnika Królestwa Polskiego z dnia 2/14 października 1867 r. zakazujące wszelkich zgromadzeń złożonych z więcej niż trzech osób. Zakaz ten objął również zebrania $\mathrm{w}$ domach prywatnych. Zabawa urządzana w domu wymagała pozwolenia, które rozporządzenie oberpolicmajstra Warszawy z 1867 r. zmieniło w obowiązek uprzedniego zawiadomienia o mającym się odbyć spotkaniu ${ }^{20}$.

${ }^{16}$ W. Miklaszewski, A. Okolski, S. Budziński, Podręcznik dla sądów gminnych Królestwa Polskiego, t. 2, Warszawa 1876, s. 397.

${ }_{17}$ F. Nowodworski, Tolerancyja religijna, „Gazeta Sądowa Warszawska”, 1905, nr 33, s. 527.

18 Dziennik Praw Królestwa Polskiego t. 42, nr 129, s. 11-238.

19 J. Gryniakow, Ekumeniczne dążenia protestantyzmu polskiego od traktatu warszawskiego 1767/68 do II wojny światowej, Warszawa 1972, s. 54-55.

${ }^{20}$ Wskazany akapit jest powtórzeniem ustaleń zawartych w: K. Grzybowski, Historia Państwa i Prawa Polski, t. IV: Od uwłaszczenia do odrodzenia Państwa, Warszawa 1982, s. 138. 
Ingerencja policyjna stała się na tyle mocna, że posiadający w Królestwie Polskim silną pozycję społeczną Kościół katolicki musiał pod groźbą kary przy urządzaniu procesji, pielgrzymek czy nawet pochodów pogrzebowych, uprzedzić zawczasu właściwą władzę policyjną o swoich planach, podając miejsce, czas i przebieg przedsięwzięcia ${ }^{21}$.

Wierni mogli występować o zgodę na publiczne nabożeństwo za pośrednictwem swoich duchownych. Dyrektor zawiadujący sprawami duchownymi w okólniku z 6/18 czerwca 1867 r. wytłumaczył na przykładzie Kościoła katolickiego, że w przypadku chęci odbycia przez wiernych procesji czy też jakichkolwiek innych zgromadzeń poza kościołem, proboszcz lub dziekan mają obowiązek uprzedniego złożenia podania o możliwość odbycia zgromadzenia, które rozpatruje naczelnik powiatu. W przypadku pozytywnego załatwienia sprawy naczelnik powiatu, jeżeli istniała taka potrzeba, miał delegować strażnika, aby w przypadku pojawienia się wrogich akcentów przerwać nabożeństwo ${ }^{22}$.

Klasztor unitów w Warszawie był w gorszej sytuacji niż inne chrześcijańskie świątynie - § 29 Przepisów z dnia 8/20 sierpnia 1865 r. o środkach utrzymania i sposobie zarządu warszawskiego klasztoru Greko-Unickiego ${ }^{23}$ stanowił, że należy zawiadamiać policję miejscową o wszystkich uroczystościach klasztornych, w trakcie których pobożni udają się do klasztoru w celach religijnych, aby władza mogła dopilnować należytego zachowania porządku.

Prawo unitów do samostanowienia religijnego zostało zrównane z prawami wyznawcami prawosławia w 1875 r. podczas formalnego przyłączenia Kościoła greckounickiego do Cerkwi rosyjskiej. Obowiązujące regulacje sankcjonowały pogląd, że skoro unitów w Królestwie Polskim już nie ma, gdyż formalnie wszyscy przystąpili do Kościoła prawosławnego wraz z duchowieństwem, to każda osoba, która dopełniła jakikolwiek obrzęd kościelny w cerkwi unickiej była uznawana za osobę prawosławną ${ }^{24}$. Wykluczało to możliwość zmiany wyznania na obrządek łaciński. Omówione prawo karne surowo zabraniało świadczenia posług religijnych unitom przez jakichkolwiek duchownych nieprawosławnych. Byli unici nie mogli bezkarnie w zaciszu domowym kultywować wiary innej niż prawosławie.

Żydzi również nie cieszyli się swobodą odprawiania zbiorowych modlitw poza przeznaczonymi do tego budynkami. Nawet za czasów obowiązywania ukazów tolerancyjnych musieli oni wyjednywać pozwolenia na prywatne modlitwy.

${ }^{21}$ W. Makowski, Prawo o Stowarzyszeniach, zwiąkach i zgromadzeniach publicznych, Warszawa 1918, s. 58-59.

${ }^{22}$ W. Jemielita, Krzyże przydrożne w Guberni Łomżyńskiej w latach 1867-1914, „Studia Teologiczne" 1989, nr 7, s. 73.

${ }^{23}$ Dziennik Praw Królestwa Polskiego t. 63 nr 200, s. 176-189.

${ }^{24}$ J. Lewandowski, Likwidacja obrządku greckokatolickiego $w$ Królestwie Polskim $w$ latach 1864-1875, 1966, s. 213-244. 
Każda osoba użyczająca Żydom lokal bądź pomieszczenie na modlitwy prywatne bądź publiczne bez wymaganego pozwolenia podlegała karze na podstawie art. $48^{3}$ Ustawy o karach wymierzanych przez sędziów pokoju ${ }^{25}$.

Stwierdzić zatem należy, że konsekwentnie stanowione od 1848 r. i zapoczątkowane wprowadzeniem Kodeksu Kar Głównych i Poprawczych prawo było nieprzyjazne dla wszystkich wyznań poza prawosławiem. Jego głównym zadaniem było utrudnianie sprawowania kultu i prowadzenia działalności misyjnej oraz dyskryminowanie poszczególnych wyznań w taki sposób, aby z czasem znaczna część mieszkańców przyjęła religię państwową, która miała umacniać carskie panowanie i scalać Imperium Rosyjskie.

Zmianę przyniosły ustawy tolerancyjne, których wydanie zostało wymuszone kryzysem władzy w latach 1905-1906. W ich wyniku prawo karne zostało zliberalizowane. Na podstawie Najwyższego ukazu imiennego z dnia 25 czerwca/8 lipca $1905 \mathrm{r}^{26}$ anulowano zasądzone kary i umorzono postępowania karne toczące się w sprawach o:

- niedoniesienie władzy o bluźnierstwie, o lżeniu świętych, Pisma Świętego i sakramentów, lub o potępianiu wiary chrześcijańskiej w ogóle, a prawosławnej w szczególności;

- odciągnięcie kogoś od wiary chrześcijańskiej na rzecz niechrześcijańskiej, o ile nastąpiło bez żadnego gwałtu;

- przejście z wiary chrześcijańskiej na niechrześcijańską;

- odwodzenie od wyznania prawosławnego na inne wyznanie chrześcijańskie, o ile nastąpiło bez żadnego gwałtu;

- przejście z wyznania prawosławnego na inne wyznanie chrześcijańskie;

- ochrzczenie lub wychowywanie swych dzieci według zasad innego wyznania chrześcijańskiego przez rodziców, którzy wedle prawa byli obowiązani wychowywać je w wierze prawosławnej;

- przeszkadzanie komuś w dobrowolnym przyłączeniu się do Kościoła prawosławnego, o ile działo się to bez żadnego gwałtu;

- zaniedbanie należytych środków gwoli powstrzymania żony, dzieci albo innych osób pozostających pod dozorem lub pieczą od zamierzonego przez nich odstępstwa od wiary prawosławnej;

${ }^{25}$ „Winny użyczenia bez zezwolenia władzy swego domu, lub innego należącego doń lub przez niego zajmowanego pomieszczenia dla odprawienia w nim przez Żydów publicznego lub wspólnego nabożeństwa, na odprawienie którego poza obrębem miejsc na to przeznaczonych, wymaganem jest wedle prawa zezwolenie władzy, ulegają karze pieniężnej do trzystu rubli”. Artykuł ten wszedł w życie mocą nowelizacji ustawy o karach wymierzanych przez sędziów pokoju z dnia 18 czerwca $1882 \mathrm{r}$.

${ }^{26}$ F. Nowodworski, Tolerancyja religijna, „Gazeta Sądowa Warszawska”, 1905, nr 31, s. 497. 
- świadome, ze strony duchownych innych wyznań chrześcijańskich, dopuszczenie prawosławnego do spowiedzi, komunii lub namaszczenia olejem św.;

- świadome, ze strony duchownych innych wyznań chrześcijańskich, spełnienie nad prawosławnym konfirmacji, bierzmowania lub obrządku znamionującego przyjęcie na łono danego Kościoła, jak też ochrzczenie przez tych duchownych według obrządków swojej wiary dzieci osób prawosławnych;

- krzewienie istniejących herezji i odszczepieństw od Kościoła prawosławnego lub zakładanie nowych sekt szkodliwych dla wiary;

- ponowny (po powrocie z zesłania) powrót do herezji lub odszczepieństwa;

- bezprawne rozdawanie, sprzedaż lub rozpowszechnianie ksiąg religijnych starego obrządku;

- tworzenie odszczepieńczych zgromadzeń lub schronisk;

- ,połączone z wyzyskaniem ciemnoty przeciągnięcie na wiarę mahometańską, żydowską lub pogańską poddanego rosyjskiego wyznającego jaką bądź inną wiarę niechrześcijańską".

Ukaz zaznaczał, że w przypadku popełnienia darowanych przestępstw po dniu jego ogłoszenia, władze miały ustalać, kto wskazane przestępstwa popełnił, wytaczać postępowania i je zawieszać (zawieszenie miało przerwać bieg terminu przedawnienia) do czasu wejścia w życie postanowień wyznaniowych zawartych w Kodeksie karnym Tagancewa z dnia 22 marca/4 kwietnia 1903 r., które zasadniczo według zatwierdzonego w 1903 r. projektu karały darowane przestępstwa. Sprawa omawianych przestępstw ostatecznie zakończyła się w ten sposób, że nikt nie został już za nie ukarany, ponieważ zostały uchylone Ukazem z 14/27 marca 1906 r., który dotyczył wprowadzenia części przepisów wyznaniowych kodeksu Tagancewa.

Liberalizację dotyczącą publicznego sprawowania kultu, choć nie dla wszystkich przyniósł dopiero Ukaz tolerancyjny z dnia 17/30 kwietnia 1905 r. o utwierdzeniu zasad tolerancji religijnej oraz Ukaz z dnia 17/30 października 1906 r., który dawał możliwość rejestrowania gmin wyznaniowych. Biorąc pod uwagę, że teren Imperium Rosyjskiego zamieszkiwało około 20 milionów starowierców i sekciarzy, były to bardzo doniosłe akty prawne ${ }^{27}$.

Ukaz z dnia 17/30 kwietnia 1905 r. stanowił, że należy:

- ,ustalić w prawie różnicę pomiędzy obrządkami, objętymi mianem odszczepieństwa (,raskoł”) i podzielić je na trzy grupy: a) zbory dawnego obrządku, b) sekty i c) obrządki zabobonne, do których samo należenie jest ścigane na drodze karnej" (art. 5);

- „uznać, że przepisy ustawy nadające prawo odprawiania nabożeństw publicznych i określające położenie odszczepieństwa (,raskoła”) w obliczu prawa

${ }^{27}$ R. Pipes, Rosja Carów, Warszawa 2006, s. 252. 
obejmują zwolenników zarówno zborów dawnego obrządku, jako też doktryn sekciarskich. Dopuszczenie się zaś z pobudek religijnych pogwałcenia praw ściąga na sprawców tego pogwałcenia odpowiedzialność, w ustawie określoną" $(\text { art. 6) })^{28}$;

- „ustalić miano: wyznawców dawnego obrządku, zamiast używanej obecnie nazwy: odszczepieńców (,raskolnikow”) dla zwolenników wszystkich tych doktryn i sekt, które przyjmują dogmaty zasadnicze kościoła prawosławnego, nie uznają zaś niektórych obrządków tego kościoła i odprawiają swoje nabożeństwo wedle ksiąg dawnego autoramentu" (art. 7);

- ,dla osób duchownych, przez gminy dawnego obrządku lub sekciarzy obieranych, gwoli spełnianiu posług religijnych, ustalić miano "przełożonych i kierowników«, przyczem osoby te, po zatwierdzeniu na urzędach przez właściwą zwierzchność rządową, mają być wyłączane ze stanu mieszczańskiego lub wieśniaczego, o ile do stanów tych należały, zwalniane od poboru do służby wojskowej czynnej i, za zezwoleniem wspomnianej zwierzchności cywilnej, nazywane imieniem przyjętem przy postrzyżynach. Niemniej pozwolić, aby w wydawanych im paszportach, w rubryce wskazującej rodzaj zatrudnienia, oznaczano godność należną im pośród danego duchowieństwa, bez używania jednak nazw hierarchicznych prawosławnych" (art. 9);

- ,wymienionym osobom duchownym pozwolić na swobodne odprawianie posług religijnych zarówno w domach prywatnych lub w domach modlitwy, jako też i w innych w razach potrzebnych, z zakazem jedynie przywdziewania szat duchownych kościelnych, jeżeli prawo tego zabrania. Przełożonym tym i kierownikom, przy zaświadczaniu testamentów, nadać takież same prawa, $\mathrm{z}$ jakich $\mathrm{w}$ tym razie korzystają w ogóle wszystkie osoby duchowne" (art. 10).

Ukaz z dnia 17/30 października 1906 r. pozwalał zarejestrować gminę wyznaniową. Zarejestrowana gmina uzyskiwała możliwość budowania domów modlitwy oraz innych odpowiadających jej lokali, odprawiania w należących do niej świątyniach i domach modlitwy publicznych nabożeństw, wybierania swoich władz i duchownych, otwierania zakładów dobroczynnych oraz szkół, nabywania i zbywania nieruchomości celem realizacji zadań statutowych gminy. Mogła ona również tworzyć fundusze, zawierać umowy, zaciągać zobowiązania, jak również pozywać i być pozywaną.

${ }^{28}$ „Rosyjskich dysydentów religijnych dzieli się zwykle na dwie grupy: starowierców, czyli staroobrzędowców (staroobriadcy), jak nazywali sami siebie bądź rozłamowców (raskolniki), jak nazywał ich oficjalny Kościół oraz sekciarzy. Pierwsi, których więcej mieszkało w tajdze, odrzucili reformy Nikona i praktykowali stare obrzędy, ale poza tym pozostali wierni prawosławiu. Drudzy odeszli mniej lub bardziej świadomie od doktryny i liturgii Kościoła prawosławnego, tworząc nowe formy religii, które stały się z czasem bliższe wczesnemu protestantyzmowi niż prawosławiu. $\mathrm{Ci}$ tradycyjnie najliczniej mieszkali na Ukrainie”- R. Pipes, op.cit., s. 249. 
Wadą przytoczonych przepisów było to, że zatwierdzeniu podlegała niezależna gmina wyznaniowa, a nie wyznanie. Choć przepisy stanowiły, że tylko osoby odpadłe od prawosławia mogły powołać do życia własną wspólnotę ${ }^{29}$, to zdarzały się przypadki, że na podstawie omawianego prawa rejestrowano również podmioty zakładane przez osoby, które porzuciły inne wyznania ${ }^{30}$.

Prawo dotyczące ramowej rejestracji gmin wyznaniowych osób, które porzuciły inne wyznanie niż prawosławne do końca istnienia Imperium Rosyjskiego nie zostało ustanowione, podobnie jak prawo pozwalające oddolnie gromadzić się i stowarzyszać wiernym w celach wyznaniowych.

Ukaz z dnia 4/17 marca 1906 r. o przepisach tymczasowych o zgromadzeniach stanowił wprost, że nie ma on zastosowania do zgromadzeń religijnych lub w celu modlitwy. Analogicznie było z Ukazem z dnia 4/17 marca 1906 r. o przepisach tymczasowych o stowarzyszeniach i związkach. Senat Rządzący sprawujący sądy w Imperium Rosyjskim uznał, że wskazany ukaz o stowarzyszeniach nie dotyczy: a) Litewskiego Oświatowego Stowarzyszenia „Światło”, b) Litewskiego Katolickiego Stowarzyszenia Kobiet, c) Polskiego Katolickiego Stowarzyszenia „Zorza”, d) Litewskiego Katolickiego Stowarzyszenia Kobiet Św. Zyty, ponieważ „jak widać z ustaw wymienionych stowarzyszeń (tj. statutów) zadaniom ich nie jest obcy kierunek religijny, a zatem stowarzyszenia te nie powinny były być rejestrowane stosownie do p. 1 art. 4 przepisów tymczasowych o stowarzyszeniach i związkach (Ukaz Senatu z d. 27 czerwca 1912 r.).

Podsumowując: choć na terenie Królestwa Polskiego w latach 1815-1905 oficjalnie istniała wolność kultu, to $\mathrm{w}$ zderzeniu z obowiązującymi przepisami i realizowaną przez władze polityką trudno mówić o prawie do swobodnego organizowania nabożeństw i prowadzenia działalności misyjnej. W świetle przedstawionego stanu prawnego do czasu wejścia w życie ogłoszonego w dniu 20 lipca 1818 r. Kodeksu Karzącego Królestwa Polskiego ${ }^{32}$ możliwość odprawiania nabo-

${ }^{29}$ Wstęp ukazu brzmiał następująco: „kontynuując to dzieło pokoju i miłości uznaliśmy obecnie za wskazane, w celu uregulowania życia wewnętrznego wymienionych zjednoczeń i odłamów, określić ścisłymi przepisami sposób zakładania i działalności gmin staroobrzędowców i sekciarzy oraz prawa i obowiązki należących do tych gmin wyznawców zjednoczeń staroobrzędowych i sekciarzy, którzy porzucili prawosławie, polecając jednocześnie Ministrowi Spraw Wewnętrznych staranie o możliwie szybkie opracowanie prawa o sekciarzach, którzy porzucili inne wyznanie chrześcijańskie". Wskazany tekst wstępu w języku polskim znajduje się w: J. Sawicki, Studia nad położeniem prawnym mniejszości religijnych w państwie polskim, Warszawa 1937, s. 360.

${ }^{30} \mathrm{H}$. Świątkowski, Wyznania religijne w Polsce ze szczególnym uwzględnieniem ich stanu prawnego. Część I. Wyznania i związi religijne, Warszawa 1937, s. 47.

31 W. Makowski, Prawo o Stowarzyszeniach..., s. 9-10. Ponadto we wskazanym opracowaniu znajdują się liczne inne ciekawe orzeczenia Senatu Rządzącego; m.in. Senat doszukał się działalności wyznaniowej w Towarzystwie Bibliotek Parafialnych Archidiecezji Warszawskiej.

${ }^{32}$ Dziennik Praw Królestwa Polskiego tom 5 nr 20, s. 3-292. 
żeństw była najszersza ze względu na przepisy konstytucji i odziedziczonego po Księstwie Warszawskim prawa wzorowanego na Kodeksie Napoleona, sporządzonego w duchu religijnej indyferencji.

Od czasu wejścia w życie Kodeksu Karzącego Królestwa Polskiego możliwość sprawowania przez wyznawców kultu publicznego oraz prywatnego zaczęła podlegać ograniczeniom związanym z zakazem propagandy religijnej niechrześcijan względem chrześcijan oraz zakładaniem nowych sekt. Istniała w majestacie prawa, za przyzwoleniem władz, możliwość sprawowania kultu prywatnego oraz publicznego przez przedstawicieli religii w jakichkolwiek sposób prawem uznanych. Nabożeństwa te mogły odbywać się poza miejscami prawem do tego przeznaczonymi tylko na podstawie przepisów szczególnych bądź administracyjnych przyzwoleń. Prawo przewidywało możliwość odprawiania nabożeństw domowych w prywatnym gronie rodzinnym, jeżeli nie miały one na celu przeciągnąć jakiegokolwiek chrześcijanina na wyznanie niechrześcijańskie.

Największe obostrzenia przyniósł obowiązujący od 1 stycznia 1848 r. Kodeks Kar Głównych i Poprawczych, wspierający religię prawosławną. Organizując kult na podobnych jak wyżej przedstawione zasadach, wierni wyznania niedominującego musieli uważać, by nie brały w nim udziału osoby chociażby formalnie zaliczane do prawosławnych. Dotyczyło to zarówno kultu publicznego, jak i prywatnego. Dodać należy, że niektóre wyznania prawnie uznane borykały się z problemami związanymi z administracyjnym zamykaniem świątyń ${ }^{33}$, co sprawiało, że dana wspólnota traciła miejsce, w którym na ogół bez specjalnych pozwoleń i zapowiedzi mogła sprawować kult.

Po wprowadzeniu przepisów tolerancyjnych i reformie prawa karnego sytuacja się poprawiła, dzięki prawu do zmiany wyznania przez prawosławnych, a w szczególnych przypadkach do odstąpienia od chrześcijaństwa. Nadal można było zostać skazanym za szerzenie kultu prawem zabronionego. Pojawiła się możliwość zakładania gmin wyznaniowych, co swobodnie mogli robić tylko apostaci z prawosławia. Gminy takie mogły budować domy modlitwy i sprawować publiczny oraz prywatny kult. Wadą carskich regulacji było to, że choćby osoby formalnie będące chrześcijanami były zagorzałymi przeciwnikami chrześcijaństwa czy też prezentowały postawy areligijne, to na forum publicznym nie mogły zadeklarować bezwyznaniowości ani formalnie zostać niechrześcijanami, ponieważ pociągało to za sobą konsekwencje związane między innymi z prawem rodzinnym.

${ }^{33}$ Np. na podstawie Ukazu z dnia 27 października/8 listopada 1864 r. o klasztorach rzymskokatolickich w Królestwie Polskiem przystąpiono do kasaty szeregu zakonów męskich i żeńskich - Dziennik Praw Królestwa Polskiego t. 62, nr 192 s. 406-419. 


\title{
CRIMINAL LAW IN THE KINGDOM OF POLAND \\ BETWEEN 1815 AND 1905 IN RELATION TO EXERCISING RELIGIOUS CULT
}

\begin{abstract}
The article pertains to the law in force in the Kingdom of Poland between 1815 and 1905. Furthermore, it indicates the changes which were brought about by the liberalization of statutes and regulations concerning faith in 1906. The main aim is to familiarize readers with the contemporary criminal law pertaining strictly to conducting private and public services as well as to draw attention to regulations delineating missionary work. The paper is general in character because presenting a detailed picture of each faith with an enumeration of their legal, civil and political limitations is a topic for a more comprehensive study.
\end{abstract}

\section{LE DROIT PÉNAL DU ROYAUME DE POLOGNE DANS LES ANNÉES 1815-1905 ET L'EXERCICE DU CULTE RELIGIEUX}

\section{Résumé}

L'article concerne la loi applicable dans les années 1815-1905 au Royaume de Pologne et signale les changements apportés par la libéralisation des règlements religieux de 1906. Sa tâche principale est de présenter le droit pénal de l'époque relatif strictement à la célébration des messes privées et publiques et d'évoquer les dispositions régissant l'activité missionnaire. L'étude est de nature générale, car la présentation de la situation détaillée de différentes confessions religieuses avec l'analyse de leurs restrictions juridiques, civiles et politiques constitue un sujet pour une vaste monographie. 